\title{
NOTE ON AN OLD BILL OF LADING FROM SURINAM
}

BY

THOMAS E. PENARD

The early commerce between Surinam and New England was hampered by restrictions imposed by the StatesGeneral in 1682, but owing to the difficulty of transporting from Europe the horses so much needed by the planters, an illicit trade with Boston, Rhode Island, and New Netherland was smiled upon by the authorities in Surinam, contrary to the regulations of the West India Company. This commerce was permitted to flourish until 1696, when the directors of the Geoctroieerde Societeit van Suriname prohibited all foreign trade. Upon protest from the governor the ban was lifted, permitting the importation of horses, cows and other live stock, and food products, and the exportation of molasses, rum, and wood. In 1699 the lid was again put on, but was removed in 1704, restricting foreign exportation, however, to molasses, rum, and Dutch manufactured goods.

The writer has in his collection an old bill of lading of goods shipped by Isaac Royall to Benjamin Gallup of Boston. It is dated Surinam, May 15, 1703, and is interesting because it was made out before the restrictions were removed, and because it specifies at least one commodity, i. e. pickled limes, not before mentioned, I believe, among permissible exports.

The old handwriting is not always very clear, but so far as I am able to decipher it the document reads:

Shipped by the grace of God in good Order, and well Conditioned by Isaac Royall in and upon the good Ship called the Hanah whereof is Master for the present Voyage 
John Green and now ridding at Anchor in the Riuer of Surinam and by God's Grace bound for Boston In new england - to say - aleuen [eleven] hhds One terce and three barrells of malasses one barrell and half of pickled limes aleuen buckanears [?] one Cerbyen [Carbine] two pestells [pistols] two hundred and fifty nine Eyorn [Iron] hups [hoops] being marked and numbred as in the Margent, and are to be delivered in the like good Order and well Conditioned at the aforesaid Port of Boston (the danger of the Seas only excepted) unto mr. Benjaman Gallup marcht. In Boston or to His Assigns, he or they paying fraight for the said goods Sixtean pounds tenn Shillings for the hoell [whole] with Primage and Avarage accustomed. In witness whereof the Master or Purser of the said Ship hath affirmed to two Bills of Lading all of this tenor and date, the one of which two Bills being accomplished the other one to stand void. And so God send the good Ship to her desired Port in safety. Amen. Dated in Surinam Maye the 15 th 1703 .

The Number and Weight of the hoops Unknown to John Green.

Preserved in the Greenough collection in the library of the Massachusetts Historical Society, there is an invoice of the same shipment of goods to Benjamin Gallup. It bears the same date as the bill of lading, and is signed „I. Royall” with a cross after the name, indicating that Mr. Royall was not able to sign his name himself. In this invoice we find further details in regard to the quantities, and also the values placed on the separate items, as follows:

aleuen hhds of Malasses Contan. II2I Galls.

One terce of ditto $\quad q t$. . . . . . . 65

three barrells of ditto $q t$. . . . . . .95 Guildrs Stirs

Makes In the Whole I28I gallons at $8 s t$. . . . $f 512 ; 8$

to the Caske . . . . . . . . . . . . f $120 ; o$

the Custom one [on[ ditto at $2^{1} / 2$ p. Cent . . . . f 012 ; IO

aleuen Buckanears at 12 guilders p. ps. . . . . $f 132 ; 0$

one Cerbien [Carbine] and two pestells [pistols] . for5; o

Two hundred and fifty nine Iorn [Iron] huppes

[hoops] qt. I295 lb. at 2 stivers $p^{s}$. . . . . . $\frac{f 129 ; 10}{f 921 ; 8}$ 


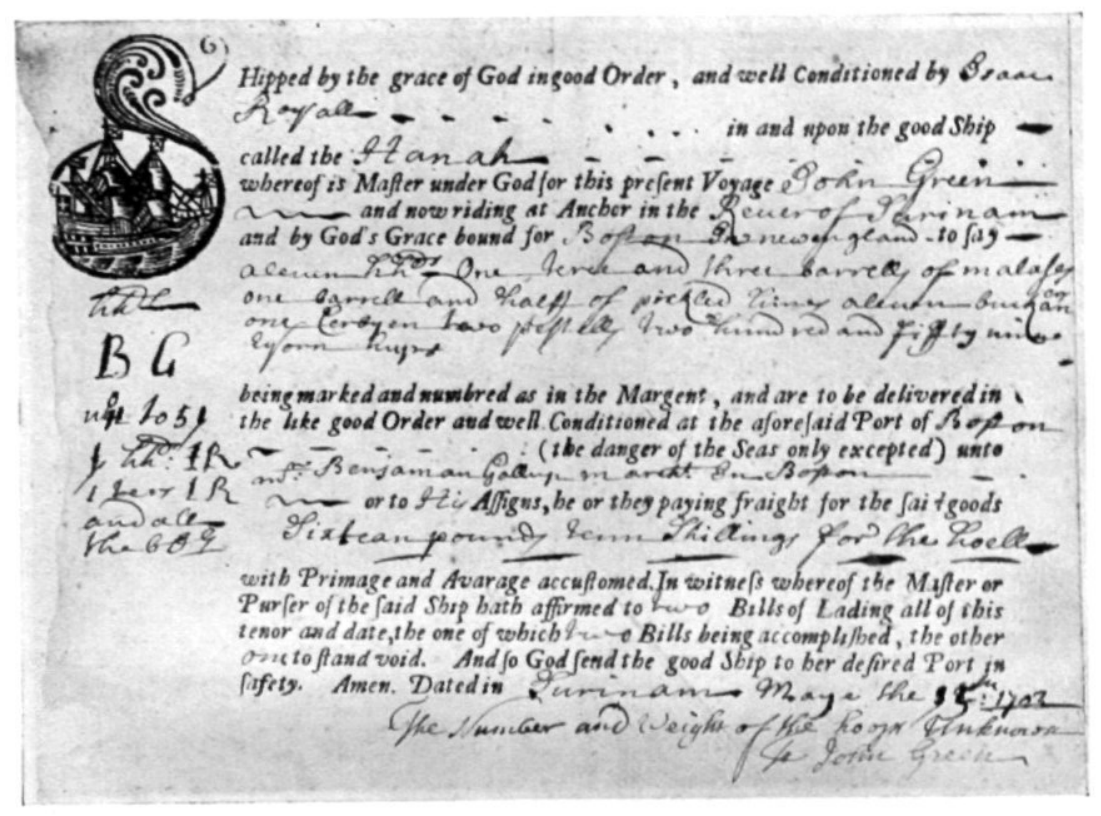

An old bill of lading from Surinam 
At the bottom there is a note referring to four barrels of rum that had been sold and for which Mr. Gallup had been paid; and also a sworn statement, dated, Boston, 25 December, 1703, and signed by Penn Townsend, Justice, to the effect that this is a true copy of the invoice of goods.

The bill of lading and the invoice do not agree in that the barrel and a half of pickled limes does not appear in the invoice; nor do we find anything about the four barrels of rum on the bill of lading. The pickled limes may have been for consumption on shipboard.

In Savage's $A$ Genealogical Dictionary of the First Settlers of New England we find mentioned a John Green of Malden (near Boston), who was a mariner and who had a daughter named Hannah. Very likely this is the John Green who was master of the brigantine Hannah.

We also find a Benjamin Gallup or Gallop, son of Nathaniel, and grandson of John Gallop whose name Gallop's Island in Boston Harbor bears. Benjamin Gallup was active in the town affairs of Boston. In the Reports of the Record Commissioners of the City of Boston we find that at a "publicke meeting of the freeholders and other inhabitants," March 9, 1695, he was elected a Constable and at a public town meeting, March 14, 1698, he was chosen Clerk of the Market.

The Royall, Royal, or Ryall family, was represented by several Isaacs, but one in particular, born about 1672 , who spent forty years in the West Indies (Antigua is mentioned), and who returned in 1637, was perhaps the Isaac Royall of the bill of lading and invoice.

I am indebted ot Mr. Julius H. Tuttle, Librarian of the Massachusetts Historical Society, for a copy of the invoice in the Greenough collection, and to Mr. Samuel C. Clough of the Colonial Society of Massachusetts for references to the genealogy of the family names which appear in these old papers. 